\title{
FRAMEWORK FOR ASSESSING SERVICEABILITY AND SOCIO-ECONOMIC RISK ASSOCIATED WITH PPPS PROJECTS IN LIBYA
}

\author{
Mohammed MARZOUK, Mahmoud EL-HESNAWI* \\ Department of Construction Engineering and Management, Faculty of Engineering, Cairo University, Egypt \\ Received 17 April 2018; accepted 06 August 2018
}

\begin{abstract}
On a global scale, limited financing for the development and operation of infrastructure projects has pushed authorities to encourage private investors to enter public-private partnerships (PPPs). In this respect, procurement of infrastructure projects such as bridges, water plants, airports, and roads has been adopted through PPPs. This has also applied to the oil-rich country of Libya which experienced severe economic and political problems in the past decade. This paper presents a systematic framework for risk assessment and appraisal of PPPs infrastructure projects. This framework is capable of identifying probable adverse effects that represent key influential factors on the private sector in a socio-economic environment and related to key performance indicators (KPIs) in order to assess the operational efficiency in developing and financing infrastructure projects. This framework proposes a new integrated system that comprises of the following: fault tree, artificial neural networks, and analytical network process. The aim of this system is to ensure sustainable availability of finances that are considered essential for the development of PPPs infrastructure projects in Libya. considering different alternative funding models, it suggests a means of auditing PPPs structure to carry out improved performance for PPPs projects in Libya.
\end{abstract}

Keywords: fault tree, neural networks; analytical network process, risk analysis, public-private partnerships.

\section{Introduction}

With a growing interest for infrastructure and the enormous cost of development and activity, governments are seeking private funds to finance water plants, electric stations, health care projects, and gas pipelines and to enhance the subsequent services (Alasad, Motawa 2015). In this respect, public-private partnerships (PPPs) take public and private sectors closely in long term contracts. As for the "Build-Operate-Transfer" (BOT) projects that are supported by PPPs, a greater part of funding generally comes from banks and financial establishments in the form of loans (Attarzadeh et al. 2017).

Different approaches have been used to assess and to analysis various types of risk (Rodney, Gallimore 2002). They conclude that sensitivity, if used properly, is sufficiently robust to identify the most important variables in appraising a PPPs project. Akintoye and Chinyio (2005) have founded that risk registers or checklists are useful to identify risks. Insurance coverage and sub-contracting are the most prominent strategies for managing the risks. Fischer et al. (2010) attempted to enhance the accuracy of decision-making processes in order to overcome the lack of common standardised definition of the identified risks and the variability of risk management approaches. Thomas et al. (2003) have suggested the generic and analytic framework through "P-I" model to assess critical risk events by introducing risk probability and impact assessment framework based on fuzzy-fault tree and the Delphi method. Xu et al. (2010) developed a fuzzy synthetic evaluation model to determine an equitable risk allocation between the government and the private sector in China. Zhou and Zhang (2010) proposed a dynamic risk management system for large construction projects in China to promote adequate decision-making for risk tracking. Iyer and Sagheer (2010) introduced a hierarchical structure of PPPs through the use of interpretative structural modeling (ISM), which is used to determine risk dependencies and to prioritise risk-mitigation efforts according to the degree of dependency and drive influence of the risks. Sachs and Tiong (2009) developed a method for quantifying qualitative information on risks (QQIR) to bridge the gap between qualitative and quantitative risk assessment methods.

*Corresponding author. E-mail: alhasnawi2017@gmail.com 
Shen et al. (2005) developed a risk concession model for build-operate-transfer contract projects to assist in determining the decision of concession period that may be adequate for involving parties in the contract by using net present value (NPV). Liou and Huang (2008) incorporated risk attributes of the BOT projects into the formulation of a contractual-negotiation model to identify possible combinations of financial returns. Li and Zou (2011) attempted to improve the accuracy of risk assessment to rank risk factors of PPPs projects using the fuzzy analytical hierarchy. Dikmen and Birgonul (2006) deployed the AHP technique within a multi-criteria decision making (MCDM) framework for risk assessment of international construction projects to derive a relative risk score. Utility theory was combined with AHP by Hsueh et al. (2007) in developing a multi-criteria risk assessment model for joint-venture constructions. The risk assessment model of binding mode, which combines the AHP and the fuzzy comprehensive evaluation method was developed by $\mathrm{Fu}-$ zhou and Hong-yuan (2011) to change the characterise problem into the quantitative problem; it was applied on a new type of public project investment and financing model which depends on reasonable risk-sharing. Zichun (2012) developed an evaluation index system for the construction phase of an expressway through the back propagation artificial neural network technique to reflect the nonlinear relationship between the risk indicators; it supports decisionmaking in the text of uncertainty environment. Kurniawan et al. (2015) represented the best practice of PPPs financial models upon the most preferred financial input and output indicators by comparing three PPPs financial models that are used for project evaluation and negotiation.

A lot of research on aspects of quantitative risk assessment models in PPPs infrastructure projects was done by scholars over the last 16 years. There is no literature to incorporate the associated risks with PPPs projects in financial model to estimate the projects' viability through risk probability and related impacts on key performance indicators (KPI) where the literature review reveals that main challenge for successful infrastructure projects through PPPs is not funding but concerns the limitations of project investment in terms of risk management process aligned with sustainability aspects related to economic, sociality, environmental, and the performance for developing PPPs infrastructure projects. The literature review has revealed the following themes:

- Most of the literature studies PPPs from the perspectives of the public sector or the contracting entities but does not probe perceptions of the financiers. Rarely, risks can be seized in decision making models, and the majority of existing risk assessment contributions only represents risk allocation methods.

- Although many authors recommended the use of decision support system that is considered the common technique for conducting PPPs studies that have been justified, they lack the tools that have the ability to audit the project's structure that would assess different impacts of a risk on KPIs to be assessed.
Further developing of risk assessments that are able to capture these challenges associated to the knowledge dimension and time dynamic is needed to manage different risk strategies in a proactive manner. It is important to develop a system that considers risk impacts on the estimation of various projects' attributes pertaining to internal rate of returns (IRRs) as a decision-making criterion to provide adequate assessment to risks affecting PPPs infrastructure projects and to enhance the methodology for appraising the indicators of capital investment related to projects' performance.

\section{Proposed framework}

The framework utilises the fault tree analysis (FTA) technique to provide reliable evidences for probable risks. Then, it quantifies profit using a designated prediction model, employing the processes of analysing, and evaluating various profit-influencing risk variables using the artificial neural networks (ANNs). Based on benefits control criteria, the analytical network process (ANP) model is established to support the decision making of stakeholders; the decision making process can be broken down as follows: identifying all the possible alternatives and assessing the status of risks on KPIs. This is a principal challenge in any decision process that requires the managers to have a complete knowledge of all influencing risk events and their probabilities, in addition to the financial scheme and KPIs that constitute the developed system, named Risk Assessment and Appraisal for Public-Private Partnerships (RAA3P). The system clears the uncertainty and ambiguity inherent in PPPs long term projects from the taken finding. Figure 1 illustrates a flow diagram of the proposed RAA3P framework which has been developed using graphical user interfaces (GUI) in JAVA and MATLAB.

The comprehensive methodological framework presented in this paper has considered the dimensions that have influenced risk management process during a project's life cycle. It integrated different approaches of risksbased PPPs with different attributes of financial viability and KPIs of infrastructure project's to support the decision taken regarding whether or not they should select the investment that could enhance the development and operational efficiency to the planned targets of revenues and socio-economic benefits. The proposed framework serves as an important contribution to the body of knowledge because it introduced an integrated hybrid system for risk assessment by incorporating different artificial intelligence techniques. The PPPs contract arrangements clearly identifies what the party perceives as associated risks and provides a link to the auditing of project's scheme.

\section{RAA3P framework development}

Development of the RAA3P framework is carried out in five main steps: data collection and probabilistic modelling of risk using fault tree analysis (FTA) technique pre- 


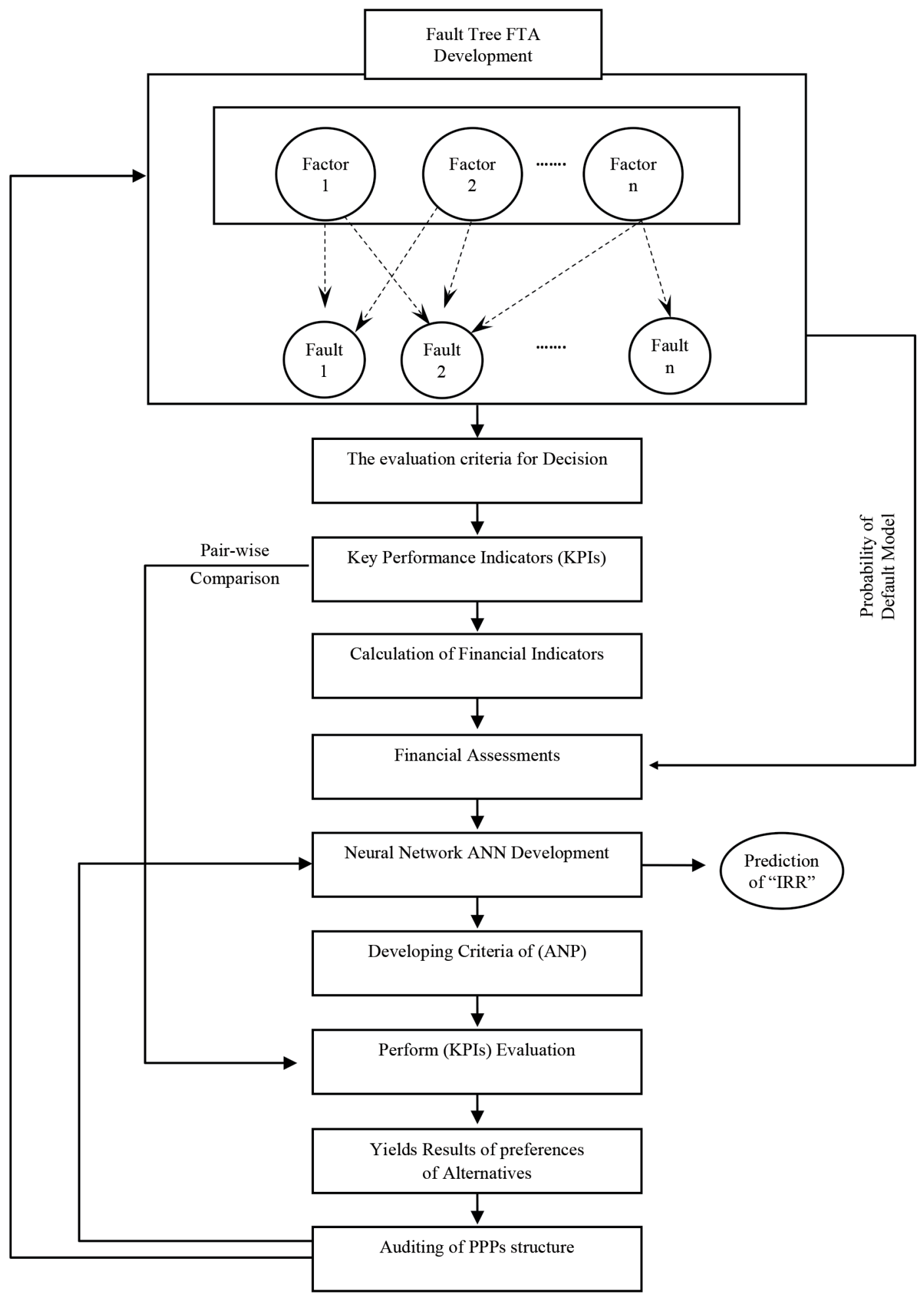

Figure 1. Flow chart of the proposed methodology

diction model for project's returns that merge analysing and evaluating various financial variables influencing risk using artificial neural network (ANN). Based on suggested alternatives and KPIs, the analytical network process (ANP) model was finally established to prioritise five alternatives to support the decision taken in auditing the project's scheme. The details of conducting processes in this paper are described in the subsections of this paper.

\subsection{Data collection}

Considering the learning experiences from the previous PPP projects, this paper utilised the questionnaire survey to gather data from risk management experts in Libya. Several intending managers were interviewed in-depth interviews - they were mangers who acquired experience in applied PPPs infrastructure projects such as project man- 
agers, risk experts, and project team members. The questionnaire survey was distributed to gather data and was drafted in relevance to in-study objectives. It determines the risk events that are associated with infrastructure PPPs projects. Furthermore, definitive statistics and hypothesis tests were used for the analysis of data based Statistical Package for Social Scientific Research Version 10.1 (SPSS). The use of the subsequent aspects of current practices of risk management process in Libya is examined.

The questionnaire used for the interviews comprises of two sections. The first section is directed on the regulatory background with the application of risk management, the number of risk occurrence, and the recording. The second section targets the utilisation of recorded risk information and segments that serve as constraints to the execution of risk management in Libya's PPP projects and their assumptions on the form and function of risk allocation.

Answers for segments 1 and 2 were solicited on the 5 -point "Likert Scale" (i.e., $0=$ not applicable, $1=$ no awareness, 2 = aware but not implemented, 3 = partially implemented, and $4=$ completely implemented). Table 1 shows the list of 21 risks related to PPPs from a variety of literature sources (Aboki 2005; Akintoye et al. 1998; Ayeni 2005; Dixon et al. 2005; Ibrahim et al. 2006; Sonuga et al. 2002; Xenidis, Angelides 2005; Yusuf 2005). Risks associated with PPPs projects were categorised and ranked in ascending order according to their significance on projects in Libya. These identified risk factors are comprehensively analysed to determine their causes and attributes whereby applicable procedures to mitigate them will be suggested later. A total of 78 copies of the questionnaire were distributed among selected participants in PPP projects. A total of 49 copies representing $62 \%$ were collected and found suitable for the analysis. Seventy percent of the respondents are experienced, having over 15 years of experience in top management level in construction field and currently involved in PPPs arrangements.

\subsection{Probabilistic modelling of risk using FTA}

The FTA is an analysing tool used in getting the probabilities of occurrence of risk events. It identifies potential causes of risk events and assesses all combinations of undesired events in the context of PPPs specific risks. The probabilities of risk event occurrence have been obtained through the fault tree approach - it yields indication to the causes that should be identified before being the undesirable event is specified (Wang, Roush 2000; Bedford, Cooke 2001). The structure of probabilistic model been developed for each of the twenty-one risks; it is composed of a sequence chain of events that involve one or more individually caused events, each with its probability of occurrence. For example: "project completion risk" is one of the 21 risks mentioned in Table 1 . It is considered a "top

Table 1. Principal risks of PPPs projects in Libya

\begin{tabular}{|c|c|c|c|c|c|}
\hline No. & $\begin{array}{l}\text { Risk } \\
\text { code }\end{array}$ & Risk factor & $\begin{array}{l}\text { Mean of occurrence } \\
\text { frequency }\end{array}$ & $\begin{array}{c}\text { Mean of effect } \\
\text { degree }\end{array}$ & $\begin{array}{c}\text { Risk-index score } \\
\text { (RI) }\end{array}$ \\
\hline 1 & P1 & Corruption-market distortion & 0.652 & 0.705 & 0.4857 \\
\hline 2 & $\mathrm{P} 2$ & Political instability risks & 0.629 & 0.743 & 0.4767 \\
\hline 3 & P3 & Termination of concession & 0.590 & 0.729 & 0.4419 \\
\hline 4 & $\mathrm{I} 1$ & Non-availability site risk & 0.567 & 0.724 & 0.4324 \\
\hline 5 & $\mathrm{I} 2$ & Project completion risk & 0.595 & 0.686 & 0.4276 \\
\hline 6 & I3 & Design changes & 0.581 & 0.705 & 0.4252 \\
\hline 7 & $\mathrm{I} 4$ & Cost and schedule overruns & 0.576 & 0.700 & 0.4195 \\
\hline 8 & I5 & Geotechnical risks & 0.562 & 0.724 & 0.4167 \\
\hline 9 & CR1 & Inappropriate concession period risk & 0.562 & 0.686 & 0.3938 \\
\hline 10 & CR2 & Contractual disputes & 0.586 & 0.652 & 0.3938 \\
\hline 11 & CR3 & Renegotiated under duress & 0.365 & 0.369 & 0.4419 \\
\hline 12 & E1 & Currency foreign exchange rate variations & 0.629 & 0.654 & 0.4276 \\
\hline 13 & E2 & Changes in taxation & 0.590 & 0.754 & 0.4252 \\
\hline 14 & E3 & Fluctuation of interest rate & 0.567 & 0.469 & 0.4195 \\
\hline 15 & $\mathrm{E} 4$ & Refinancing risk & 0.595 & 0.743 & 0.4419 \\
\hline 16 & E5 & Demand and revenue risks & 0.581 & 0.729 & 0.365 \\
\hline 17 & E6 & Debt servicing risk (difficulties) in debt-servicing & 0.629 & 0.724 & 0.547 \\
\hline 18 & $\mathrm{O} 1$ & Law enforcement risk & 0.698 & 0.686 & 0.635 \\
\hline 19 & $\mathrm{O} 2$ & Operating risk (operating deficits) & 0.864 & 0.705 & 0.654 \\
\hline 20 & $\mathrm{O} 3$ & Regulatory risk & 0.635 & 0.700 & 0.584 \\
\hline 21 & $\mathrm{O} 4$ & Force Majeure & 0.456 & & 0.591 \\
\hline
\end{tabular}


event" that is influenced by several factors such as "costoverrun" and "delay of permits", and so on. The probability of occurrence of an output event is achieving via FTAs models that are mathematically introduced as a set of Boolean equations as a result of the calculations of probabilities of two or more independent input events; they are combined by standard logic symbols called "AND-gate" and "OR-gate". A Boolean OR gate is calculated using Eqn (1); whereas Boolean AND-gate is calculated using Eqn (2) as reported by Bedford and Cooke (2001):

$$
\begin{aligned}
& P\left(A_{0}\right)=1-\prod_{i}^{n}={ }_{1}\left\{1-P\left(A_{i}\right)\right\} ; \\
& P\left(A_{0}\right)=\prod_{i}^{n}={ }_{1} P\left(A_{i}\right),
\end{aligned}
$$

where $A_{0}$ is the top event; $A_{i}$ is the input event.

The Boolean equations indicate that the top event $A_{0}$ fails if all input events $A_{i}$ fail at the same time in case of the OR gate. On the other hand, for the AND gate, the top event $A_{0}$ fails if one of input events $A_{i}$ fails. The probability of risk event occurrence is assessed based on infrastructure projects through PPPs within the Libyan environment. Whereas the risk sub-models can be re-organised by the user to illustrate the conditions that characterised the project under consideration and provides the various factors influencing the major risk events and their interrelationships.

\subsection{Development of Artificial Neural Network (ANN) tool}

Artificial Neural Network (ANN) is an analytical tool that is widely used in diverse applications to provide a simulation to a human-brain thinking manner. In this paper, the ANN model tool is developed to predict the internal rate of return (IRR) for PPPs infrastructure projects; it utilises a typical forward neural network with a regular back propagation learning algorithm to train the presented model. Table 2 lists the most influential criteria in financing a PPPs project, including perceptions about profitability, financing, organisational competence, and payback period in terms of debt service coverage ratio as well as the correlation among the financial factors' that influencing the project's rate of return.

\subsection{Building an ANP model}

The ANN, as developed by Saaty (1996) is considered a systematic way that allows the user to include all the essential criteria of the considered problem and establish their priorities. In this paper, the network was structured based on the risk profile and the KPIs to synthesise the priorities of the suggested alternatives to obtain the best decision related to the judgment of project's scheme in achievement of the target returns in the light of signified risks - the proposed model includes all the factors and applied criteria that have influenced risk assessment on supporting the decision. Through this process of analysing dependencies, the ANP utilises complicated interrelation-
Table 2. Financial data attributes of PPPs projects

\begin{tabular}{|cl|}
\hline ID & \multicolumn{1}{c|}{ Factor } \\
\hline$X_{1}$ & Primary investment, in million \\
$X_{2}$ & Leverage debt-to-equity (DE) \\
$X_{3}$ & Awarded concession period \\
$X_{4}$ & Expected revenues \\
$X_{5}$ & Net cash flow \\
$X_{6}$ & Discount rate \\
$X_{7}$ & Inflation rate \\
$X_{8}$ & Borrowing interest expense \\
$X_{9}$ & Borrowing income taxes \\
$X_{10}$ & NPV of contract \\
$X_{11}$ & Payback period \\
$X_{12}$ & Profitability Index \\
$X_{13}$ & Construction period \\
$X_{14}$ & Operation period \\
$X_{15}$ & Debt service coverage ratio (DCR) \\
Y & Required rate of return (IRR) \\
\hline
\end{tabular}

ships among decision levels in selecting one among various decision alternatives that are suggested for mitigating the quantified risks.

\section{Case study}

The case study that considered in this paper is PPPs project of highway road in Libya. It is used to illustrate the application of the RAA3P developed system. The public sector promoted private sector participation in development and operation of the highway. The government is aimed to facilitate fundamental investment and in turn enhance the existing infrastructure to gain the required new innovation, know-how, and management methods. Pertaining to the private sector, investment in highways was part of its own action plan to promote new business.

This concession contract is a high way road that was developed by the Libyan government in 1,200 kilometres, connecting Tripoli and Benghazi. It is known as the Tripoli-Benghazi toll road (TBTR). Initially conceived as a PPPs project, it developed as a 25 -year deal. The project under consideration in this paper was financed through a combination of commercial financing through government contributions and private equity. It aims to mobilise $€ 586$ million for funding the project. It was also supported by technical assistance funds from the European bank for rehabilitation and development (EBRD) from the Global Partnership for Output-Based Aid. Finally, a rate of return $21 \%$ was proposed by the concessionaire in order to match his obligations in this long-term contract. Table 3 provides further data related to the considered PPPs project case study. 


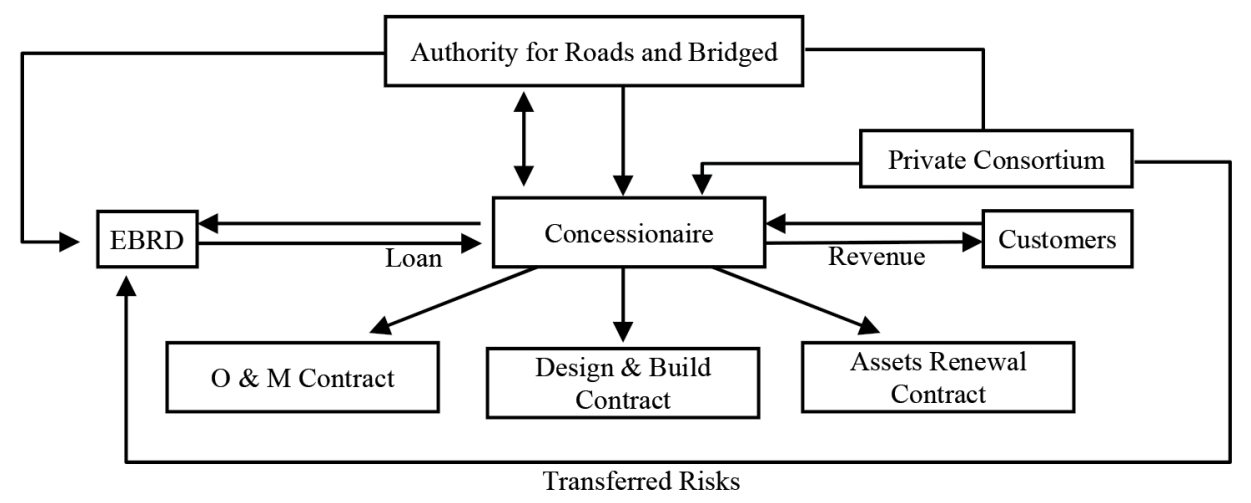

Figure 2. Structure of TBTR's project

The suggested project's scheme was developed based on relevant key performance criteria that were formulated by the public sector in order to assess the project's viability and to risk allocation as the contract arrangements for considering various projects' conditions in achieving the target returns and operational efficiency. Table 4 illustrates the KPIs of the TBTR project.

During the contract signing, it was fixed in the agreement that in the event of the project returns being beyond the predefined percentage, the toll tariff would be modified routinely. Changing the tariff was to be decided by the public sector on the ground of an application conducted by the private sector. This was in accordance to the agreement which indicates that the private consortium is in-charge of gathering tariffs and when relevant pays dividends to all investors of equity including the public sector. Figure 2 presents the project's structure that illustrates the involved contracts in the PPPs projects.

Poor governance process poses risks such as underrepresentation of the public sector in decision-making, poor correspondence streams, absence of coordination and collaboration between involving parties, and a lack of sustainable financing. Whereas revenues are considered the major source for repayments of the loans; they are sensitive to the fluctuation of exchange rate. Careful deliberation should be given to limiting the exposure of foreign exchange risk. Furthermore, good estimation of revenue cash flows in the light of encountered probable risks represent the main driver for the project's completion and

Table 3. The PPPs project case study

\begin{tabular}{|l|l|}
\hline \multicolumn{1}{|c|}{ Project } & \multicolumn{1}{|c|}{ Tripoli and Benghazi Toll Road (TBTR) } \\
\hline Sector & Roads and Bridges \\
\hline Project Structure & BOT (Finance, Build, and Operate) \\
\hline $\begin{array}{l}\text { Contract } \\
\text { Signature Year }\end{array}$ & Tripoli, (2012) \\
\hline Capital value & $\begin{array}{l}€ 418.65 \text { million is debt (15 year a loan } \\
\text { including and 4-year Grace period ) and } \\
€ 167.35 \text { is equity }\end{array}$ \\
\hline $\begin{array}{l}\text { Financial } \\
\text { Structure }\end{array}$ & EBRD loan, tariff financing \\
\hline
\end{tabular}

Table 4. Key performance indicators for the TBTR project

\begin{tabular}{|c|l|l|}
\hline No & \multicolumn{1}{|c|}{ Benefit } & \multicolumn{1}{c|}{ Factors } \\
\hline 1 & Economic & $\begin{array}{l}\text { Establishment of efficient } \\
\text { environmental regulation system. } \\
\text { Reducing government budget deficit. } \\
\text { Cost reduction due to competition. } \\
\text { Degree of risk transfer to government. } \\
\text { Securing investment resources in } \\
\text { mixed-use development. }\end{array}$ \\
\hline 2 & Financial & $\begin{array}{l}\text { Revenue guarantees. } \\
\text { Acceptable tariff levels. } \\
\text { Low construction cost. } \\
\text { Forecasts of future demands. }\end{array}$ \\
\hline 3 & Serviceability & $\begin{array}{l}\text { Assessment of assets condition } \\
\text { (updating and improving the existing } \\
\text { facility). } \\
\text { Effectiveness of cost-benefit (means of } \\
\text { providing capital improvement). } \\
\text { Prevention of bureaucratisation } \\
\text { (downsizing of government } \\
\text { operations). } \\
\text { Resource utilisation. } \\
\text { Create a higher level of operating } \\
\text { efficiency. }\end{array}$ \\
\hline Social & $\begin{array}{l}\text { Infrastructure development (increase in } \\
\text { service coverage to specific areas) } \\
\text { Improvement of land property value. } \\
\text { Introduction of advanced technology. } \\
\text { Enhance and protect the environment. } \\
\text { Create a strong team of local partners; } \\
\text { highly qualified professional in skill. }\end{array}$ \\
\hline
\end{tabular}

matches the obligations of the consortium that incorporate the risk profile in all relevant decisions in accordance with operational efficiencies. Table 5 illustrates the risk encountered within the TBTR project.

Given the interactions between contractual arrangements for a project and stream cash flows related development, it is important for all involving parties to appropriately determine the KPIs for the project; particularly on highway projects that is subjected to poor demand or high cost of investment. Whereas, the private party is accepting monetary benefits which they are attempting to attain by achieving operational efficiency and providing the 
Table 5. Risks encountered in the Tripoli-Benghazi Toll Road

\begin{tabular}{|c|c|c|c|}
\hline No. & Project Phase & Risk & Explanation \\
\hline 1 & $\begin{array}{l}\text { Construction and } \\
\text { implementation } \\
\text { phases }\end{array}$ & $\begin{array}{l}\text { Financing } \\
\text { Risks }\end{array}$ & $\begin{array}{l}\text { International loans must be repaid in currencies particular from the currencies } \\
\text { of the revenues. The repayments are subjected to exchange rate movements. The } \\
\text { floating interest rates of the loans are afflicted by an increase in real interest rates } \\
\text { and can increase the cost of the financing inadequate and unsustainable funding } \\
\text { models. }\end{array}$ \\
\hline 2 & Operation phase & $\begin{array}{l}\text { Operating } \\
\text { revenues }\end{array}$ & $\begin{array}{l}\text { The operating revenues of the project depend on the Libyan economic growth } \\
\text { since profits are the major source of paying back the loans. Careful consideration } \\
\text { should be given to limiting foreign exchange risk. Then, traffic revenues will } \\
\text { increase when the Libyan Dinar (LYD) appreciates and decrease when it devalues. }\end{array}$ \\
\hline 3 & $\begin{array}{l}\text { Construction and } \\
\text { implementation } \\
\text { phases }\end{array}$ & Political risk & $\begin{array}{l}\text { Political risk was a major factor to consider in the project. It was difficult to } \\
\text { consider the probability of poor governance, underrepresentation of the public } \\
\text { sector in decision-making, poor correspondence field, and lack of coordination } \\
\text { and collaboration between partners that ascribe to the delay of legislation } \\
\text { supporting the project in Libya. }\end{array}$ \\
\hline 4 & $\begin{array}{l}\text { Construction and } \\
\text { implementation } \\
\text { phases }\end{array}$ & $\begin{array}{l}\text { Completion } \\
\text { and operating } \\
\text { risks }\end{array}$ & $\begin{array}{l}\text { Completion and operating risks in the project were expected by lenders and } \\
\text { equity investors in the project in return for the high probable payoff of the } \\
\text { project since the contract is to assign this risk to the contractors. The contractors, } \\
\text { in turn, apportion segments of the completion risk to the shortage of equipment, } \\
\text { the setback of material suppliers, and organisational structure. Moreover, lenders } \\
\text { are not so well concealed against cost overruns and delay risks. The project cost } \\
\text { was altered by the high inflation rate in Libya and the Government was not } \\
\text { experienced enough to project the construction delays in the start-up phase and } \\
\text { closure phase of the project. }\end{array}$ \\
\hline 5 & $\begin{array}{l}\text { Design-construction } \\
\text { phase }\end{array}$ & $\begin{array}{l}\text { Construction } \\
\text { Risk }\end{array}$ & $\begin{array}{l}\text { It was unlikely that the project would be incomplete due to technical reasons } \\
\text { as the geotechnical difficulties and equipment problems were abundant. } \\
\text { Furthermore, cost overruns and construction delays were also apparent - no } \\
\text { measures were taken by project managers to control cost overruns and to go after } \\
\text { late financing. }\end{array}$ \\
\hline 6 & Operation phase & Income risks & $\begin{array}{l}\text { The initial traffic projection may have been over promising either due to } \\
\text { inaccurate estimations or the availability of alternative routes. Incomes from } \\
\text { direct tolls have fallen short of assumptions, and hence the cash flow of the } \\
\text { sponsors was at risk. }\end{array}$ \\
\hline 7 & Operation phase & Off-take risks & $\begin{array}{l}\text { Cash flow estimation is paramount for successful project financing. The highway } \\
\text { companies were supposed to speculate part of the revenue deficit risk. }\end{array}$ \\
\hline 8 & $\begin{array}{l}\text { Construction and } \\
\text { implementation } \\
\text { phases }\end{array}$ & $\begin{array}{l}\text { Conflict of } \\
\text { Interest }\end{array}$ & $\begin{array}{l}\text { Disagreements that occurred between the parties involved in the project, due to } \\
\text { the dubiousness of construction contract clauses, as well as no settle procedures } \\
\text { for the disputes that could happen between the project company and the } \\
\text { contractors. }\end{array}$ \\
\hline
\end{tabular}

sustainability of financing by managing all the revenues as planned in the light of risks and uncertainty. This is in turn affects the choice of pertinent financial structure. Risk can be transferred throughout PPPs arrangements, but it is imperative to figure out the risk of refinancing that should be perceived in the contract agreement as the private consortium bears most financial risks. Implementation of the RAA3P system as discussed in the next sections will illustrate the capability of highlighting potential inefficiencies in a PPP structure as well as inefficiencies of operation.

\section{RAA3P implementation}

Figure 3 illustrates the graphical user interface (GUI) of the MATLAB code. It is constructed based on the faulttree analysis. Herein, the estimated probability of the identified risk event "probability of occurrence" and the rating of the top event is displayed on top of the interface that rely on the known probabilities of the causes events that lead to such an identified risk. The themes of financial attributes were estimated by spread sheets which show the calculation of the financial model as depicted in Figure 4.

The analysis of the financial model, presented by the RAA3P system, is carried out from the perspective of financial sustainability. This is conducted by calculating the indices of financial return on the investment project based on the discounted cash flows. The main objective of this financial analysis is to use the project cash flow outlooks to predict the net return indicators, particularly from the perspective of the investor. This proposed approach aims to put all present and future expenses and revenues in a typical metric in order to help non-financial managers in maintaining the project's progress in the context of the net present value (NPV), payback period, profitability, and return on investment. All these attributes are listed in Table 6 . 


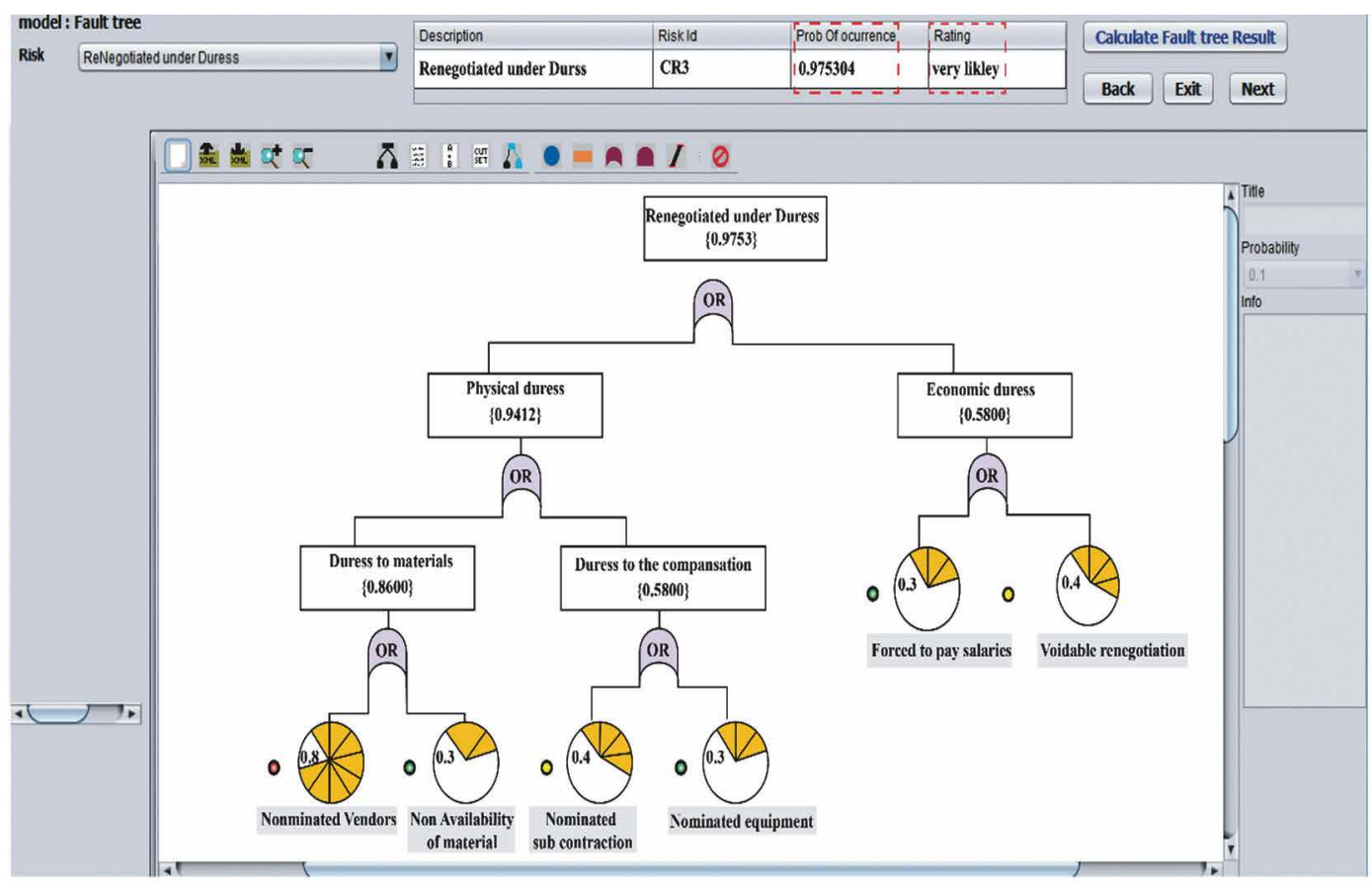

Figure 3. Probability of risk occurrence by RAA3P system

Model: Business Model
\begin{tabular}{|llll|}
\hline Financial Variables & & \\
\hline Variable & Type & equations & Value \\
\hline BORROWING INCOME TAXES & Numeric & & \\
\hline PRIMARY INVESTMENT, IN MILLION & Numeric & \\
\hline AWARDED CONCESSION PERIOD & Numeric & \\
\hline OPERATION PERIOD & Numeric & \\
\hline INFLATOIN RATE & Numeric & \\
\hline BORROWING INTEREST EXPENSE & Numeric & \\
\hline CONSTRUCTION PERIOD & Numeric & \\
\hline EXPECTED REVENUES & & \\
\hline DISCOUNT RATE & Calculate \\
\hline LEVERAGE (DEBET-TO-EQUITY (DE) & Numeric & \\
\hline
\end{tabular}

Figure 4. Business data entry sheet by RAA3P system 


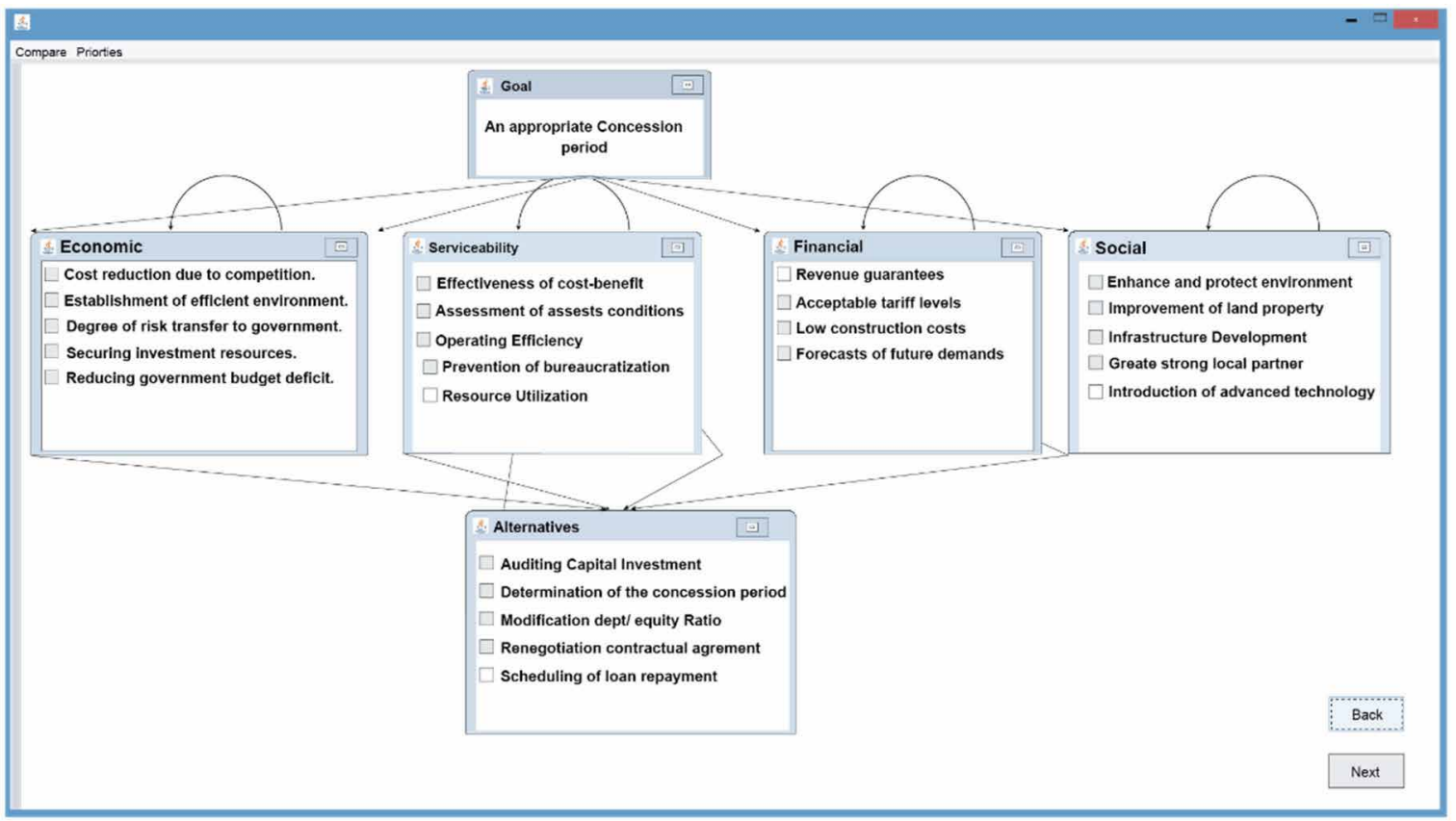

Figure 5. ANP model for key performance indicators evaluation of PPPs

Table 6. Financial evaluation index

\begin{tabular}{|l|l|}
\hline \multicolumn{1}{|c|}{ Index } & \multicolumn{1}{|c|}{ Investment } \\
\hline IRR & $3.45 \%$ \\
\hline NPV & $€ 95$ million \\
\hline Payback period & 18.4 years \\
\hline ROI & $0.71 \%$ \\
\hline
\end{tabular}

The ANP model combines their judgments that represent relations and their intensities of clusters to rank the suggested alternatives in the process of decision-making under consideration. This is done through the risk mitigation procedures based on determining the KPIs; the overall process obtains results close to the known amounts of the TBTR project. Figure 5 shows the structure of the ANP model that is constituted by the RAA3P system. It is de- scribed by its clusters and elements whereas connections between the clusters indicate the flow of influence between elements; an inner dependence exists for all clusters.

The system's user compares the impact of the risk in case to the benefits control criteria that has been used in project assessment. Alternatives to the decision were ranked according to priorities during the assessment process as shown in Figure 6. This in turn supports the decision-making process in terms of auditing and renegotiating the contract to achieve optimal IRR and optimal structure for PPPs arrangements. Several key considerations for the project partners help to ensure success of the structure usage.

\section{Analysis and discussion}

The sensitivity analysis module has evaluated the effect of different major financial variables and associated risk

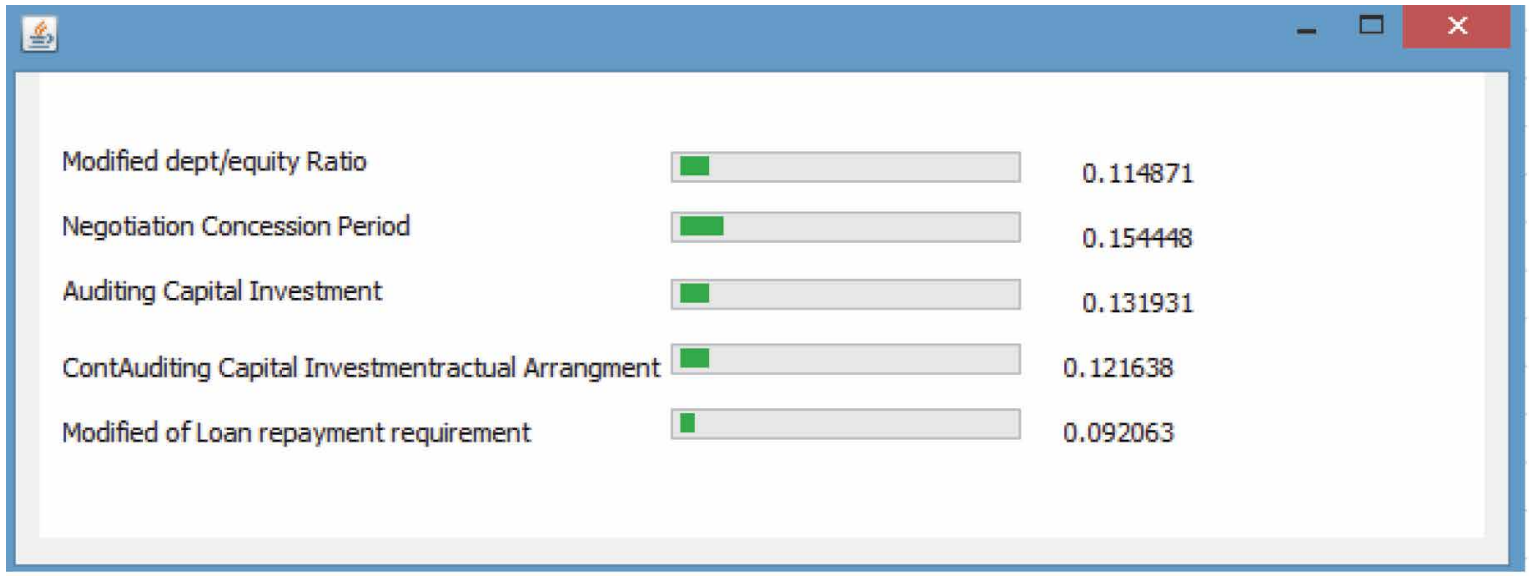

Figure 6. Local priorities of alternatives by the RAA3P system 


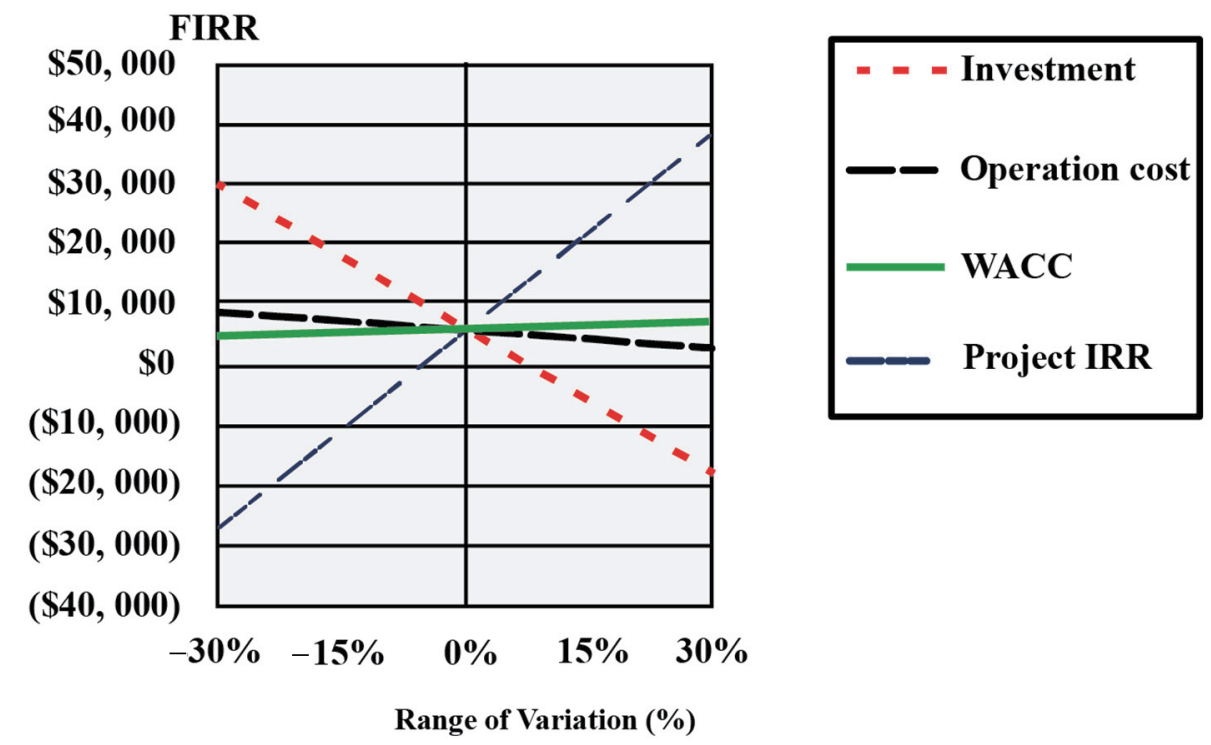

Figure 7. Schematic diagram for IRR sensitivity analysis

occurrence probability on the sensitivity for the output of IRR whereas the base case situation was developed using expected values for each input. Each variable was changed by a specific percentage beyond the expected value while holding other variables constant. The IRR is calculated for each of these values; results of IRRs sensitivity due to given changes of associated factors were listed in Table 7. It lead to deciding on applying change onto the one or more factors that govern the project's financing such as toll revenue, initial consuming, and operating period for the objective of obtaining optimal IRR. This module is capable of providing certain sensitive data in graphical
Table 7. Internal rate of return (IRR) sensitivity analysis

\begin{tabular}{|cccc|}
\hline \multirow{2}{*}{$\begin{array}{c}\text { Deviation } \\
\text { from } \\
\text { base case }\end{array}$} & \multicolumn{3}{c|}{ Toll } \\
\cline { 2 - 4 } revenue & $\begin{array}{c}\text { Project } \\
\text { investment }\end{array}$ & $\begin{array}{c}\text { Operation } \\
\text { cost }\end{array}$ \\
\hline$-30 \%$ & $-0.85 \%$ & $3.01 \%$ & $2.90 \%$ \\
$-15 \%$ & $0.58 \%$ & $2.30 \%$ & $2.30 \%$ \\
$0 \%$ & $1.70 \%$ & $1.70 \%$ & $1.70 \%$ \\
$15 \%$ & $2.99 \%$ & $1.40 \%$ & $1.60 \%$ \\
$30 \%$ & $4 \%$ & $0.92 \%$ & $0.48 \%$ \\
\hline
\end{tabular}

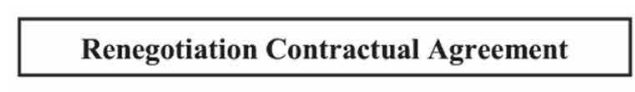

0.1084779999
Modification Debt/equity Ration

0.090411
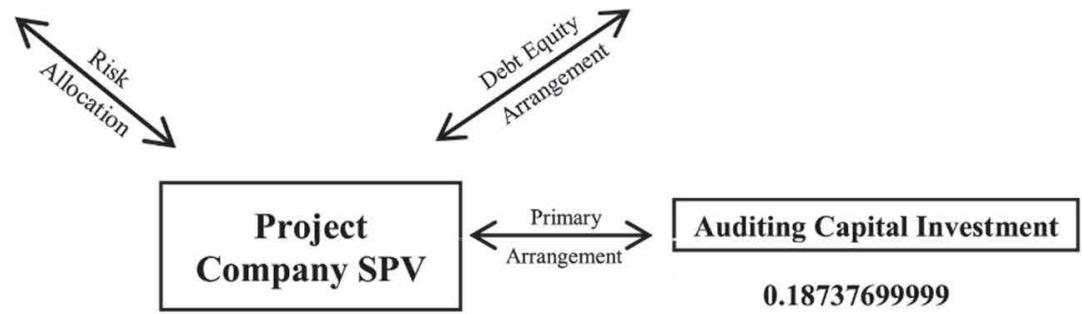

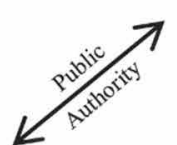

Determination of the Concession Period

0.156168000003
Scheduling of loan repayment requirement

0.1301570000002

Final Report

Figure 8. The proposed adoption of PPPs structures as RAA3P system's outputs 
format to facilitate negotiations and decision-making. It can be concluded that IRR is most sensitive to changes in toll revenue followed by operation cost and project investment. Figure 7 presents the schematic diagram for Project IRR sensitivity and the set of IRRs plotted against the variables that were changed.

The presented RAA3P system is helpful in determining the need for re-organising and auditing PPPs scheme. This system is considered a crucial tool in attracting investment in the form of new sources of funding. This paper has done this by predicting the project's returns and streams of cash flows for a long-term investment which are satisfy major requirements from the perspective of financial institutions in funding these types of projects to accomplish their interests. Figure 8 presents the proposed adoption scheme of the project with regards to the contracting parties wherein the typical structure drives the project's managers to understand the methodology used of how to diffuse the associated risks throughout the linked sub contracts. Such risks are modelled over the project's life cycle and were taken through a network of private sector companies involved in the PPP contract and the refinancing of investments. In this paper, the presented RAA3P system proposes an adoption of the project's scheme as a result of alerting to each party involved in PPPs projects to adjust their missing variables and renegotiate according to the given alternatives resulted from the ANP model in order to obtain optimal return on investment.

\section{Conclusions}

Based on the findings from this paper, the following conclusions are obtained:

- The presented RAA3P system provides a systematic framework for risk assessment of PPPs infrastructure projects. It introduces the auditing financing schemes by incorporating the analysis for the most critical risks and financial attributes that influence the track on project's scheme in line with risk mitigation principles. It incorporates a different analytical technique that combines the probabilistic assessment in terms of probability of risk occurrence, prediction performance of project-specific financial factors, and managing to rank the alternatives that support the decision based deductive reasoning technique in dealing with the uncertain environment that characterises PPPs infrastructure projects.

- The results show that the presented RAA3P system grants the private party an analytical tool to assess the effectiveness of PPPs projects over the life cycle in terms of the project's viability to achieve the targeted internal rate of return. Consequently, adoption to the project's scheme is proposed through evaluating KPI of PPPs. The TBTR case study in this paper pointed out the predicted results for IRRs that were reasonably accurate and close to those actually executed in terms of risk management process. It reflects accuracy for about of $83 \%$ for projects subjected to methodological analysis through the RAA3P system. The implication of specific risks will vary depending upon the project characteristics. While the road projects may have high development risks, low working risks, and high market risks, media transmission undertakings may have low development chances yet high market risks. Additionally, the energy projects may have high development risks, generally low operational and market risks and high instalment risk. Therefore, the proposed system in this paper extends a broad approach to assess the risks-based KPIs and alternative approaches to decision making.

- In order to enhance the developed system, assumptions of models that will constitute the modified system can be substituted. It is essential that the provided system have the ability to revise contract clauses to suggest advices to achieve the optimal risk allocation for PPPs infrastructure projects. All of this must have be done by considering different types of PPPs development methods.

\section{Acknowledgements}

The authors would like to thank Libyan roads and bridges authority experts who took part in our case study.

\section{Disclosure Statement}

No potential conflict of interest was reported by the authors.

\section{References}

Aboki, L. 2005. Mabushi BOT market: One bidder's perspective, in Proceedings of BOT Awareness Seminar, 2005, Abuja Investment and Property Development Company.

Akintoye, A.; Chinyio, E. 2005. Private finance initiative in the healthcare sector: trends and risk assessment, Engineering, Construction and Architectural Management 12(6): 601-616. https://doi.org/10.1108/09699980510634155

Akintoye, A.; Taylor, C.; Fitzgerald, E. 1998. Risk analysis and management of private finance initiative projects, Engineering, Construction and Architectural Management 5(1): 9-21. https://doi.org/10.1108/eb021056

Alasad, R.; Motawa, I. 2015. Dynamic demand risk assessment for toll road projects, Construction Management and Economics 33(10): 799-817.

Attarzadeh, M.; Chua, D. K.; Beer, M.; Abbott, E. L. 2017. Options-based negotiation management of PPP-BOT infrastructure projects, Construction Management and Economics 35(11-12): 676-692.

https://doi.org/10.1080/01446193.2017.1325962

Ayeni, K. 2005. Risk identification and management in BOT project implementation, in Proceedings of BOT Awareness Seminar, 2005, Abuja Investment and Property Development Company.

Bedford, T.; Cooke, R. 2001. Probabilistic risk analysis: foundations and methods. Cambridge: Cambridge UP. https://doi.org/10.1017/CBO9780511813597 
Dikmen, I.; Birgonul, M. T. 2006. An analytic hierarchy process based model for risk and opportunity assessment of international construction projects, Canadian Journal of Civil Engineering 33(1): 58-68. https://doi.org/10.1139/105-087

Dixon, T.; Pottinger, G.; Jordan, A. 2005. Lessons from the private finance initiative in the UK: Benefits, problems and critical success factors, Journal of Property Investment \& Finance 23(5): 412-423.

https://doi.org/10.1108/14635780510616016

Fischer, K.; Leidel, K.; Riemann, A.; Wilhelm Alfen, H. 2010. An integrated risk management system (IRMS) for PPP projects, Journal of Financial Management of Property and Construction 15(3): 260-282. https://doi.org/10.1108/13664381011087515

Fu-zhou, L.; Hong-yuan, G. 2011. The risk assessment model of BT construction engineering project financing, Systems Engineering Procedia 1: 169-173. https://doi.org/10.1016/j.sepro.2011.08.028

Hsueh, S. L.; Perng, Y. H.; Yan, M. R.; Lee, J. R. 2007. On-line multi-criterion risk assessment model for construction joint ventures in China, Automation in Construction 16(5): 607619. https://doi.org/10.1016/j.autcon.2007.01.001

Ibrahim, A. D.; Price, A. D. F.; Dainty, A. R. J. 2006. The analysis and allocation of risks in public private partnerships in infrastructure projects in Nigeria, Journal of Financial Management of Property and Construction 11(3): 149-164. https://doi.org/10.1108/13664380680001086

Iyer, K. C.; Sagheer, M. 2010. Hierarchical structural of public private partnership (PPP) risks using interpretive structural modelling, Journal of Constructional Engineering and Management 23(3): 195-205.

https://doi.org/10.1061/(ASCE)CO.1943-7862.0000127

Kurniawan, F.; Mudjanarko, S. W.; Ogunlana, S. 2015. Best practice for financial models of PPP projects, Procedia Engineering 125: 124-132. https://doi.org/10.1016/j.proeng.2015.11.019

Li, J.; Zou, P. X. 2011. Fuzzy AHP-based risk assessment methodology for PPP projects, Journal of Construction Engineering and Management 137(12): 1205-1209.

https://doi.org/10.1061/(ASCE)CO.1943-7862.0000362

Liou, F. M.; Huang, C. P. (2008). Automated approach to negotiations of BOT contracts with the consideration of project risk, Journal of Construction Engineering and Management 134(1): $18-24$. https://doi.org/10.1061/(ASCE)0733-9364(2008)134:1(18)

Rodney, W.; Gallimore, P. 2002. Risk assessment in PFI schemes for primary health care, Facilities 20(1/2): 52-60. https://doi.org/10.1108/02632770210414290

Saaty, T. L. 1996. Decision making with dependence and feedback: The analytic network process. Vol. 4922. Pittsburgh: RWS publications.

Sachs, T.; Tiong, R. L. 2009. Quantifying qualitative information on risks: development of the QQIR method, Journal of Construction Engineering and Management 135(1): 56-71. https://doi.org/10.1061/(ASCE)0733-9364(2009)135:1(56)

Shen, J. Y.; Wang, S. Q.; Qiang, M. S. 2005. Political risks and sovereign risks in Chinese BOT/PPP projects: a case study, Chinese Businessman Investment and Finance 1: 50-53.

Sonuga, F.; Aliboh, O.; Oloke, D. 2002. Particular barriers and issues associated with projects in a developing and emerging economy. Case study of some abandoned water and irrigation projects in Nigeria, International Journal of Project Management 20(8): 611-616.

https://doi.org/10.1016/S0263-7863(02)00029-7
Thomas, A. V.; Kalidindi, S. N.; Ananthanarayanan, K. A. B. T. 2003. Risk perception analysis of BOT road project participants in India, Construction Management and Economics 21(4): 393-407. https://doi.org/10.1080/0144619032000064127

Wang, J. X.; Roush, M. L. 2000. What every engineer should know about risk engineering and management. CRC Press.

Xenidis, Y.; Angelides, D. 2005. The financial risks in build-operate-transfer projects, Construction Management and Economics 23(4): 431-441. https://doi.org/10.1080/01446190500041552

Xu, Y.; Yeung, J. F.; Chan, A. P.; Chan, D. W.; Wang, S. Q.; Ke, Y. 2010. Developing a risk assessment model for PPP projects in China - A fuzzy synthetic evaluation approach, Automation in Construction 19(7): 929-943.

https://doi.org/10.1016/j.autcon.2010.06.006

Yusuf, M. L. 2005. Build Operate Transfer method of projects delivery: The AIPDC experience. Proceedings of BOT Awareness Seminar. Abuja Investment and Property Development Company.

Zhou, H. B.; Zhang, H. 2010. Dynamic risk management system for large project construction in China, in GeoFlorida 2010: Advances in Analysis, Modeling \& Design, 2010, Orlando, Florida, United States, 1992-2001. https://doi.org/10.1061/41095(365)202

Zichun, Y. 2012. The BP artificial neural network model on expressway construction phase risk, Systems Engineering Procedia 4: 409-415. https://doi.org/10.1016/j.sepro.2012.01.004 